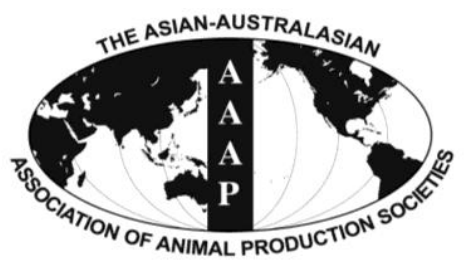

Asian Australas. J. Anim. Sci.

Vol. 26, No. 12 : 1781-1789 December 2013

http://dx.doi.org/10.5713/ajas.2013.13225

www.ajas.info

pISSN 1011-2367 elSSN 1976-5517

\title{
Effect of Modified Atmosphere Packaging and Vacuum Packaging on Quality Characteristics of Low Grade Beef during Cold Storage
}

\author{
S. J. Hur', S. K. Jin ${ }^{2, *}$, J. H. Park ${ }^{3}$, S. W. Jung ${ }^{4}$, and H. J. Lyu ${ }^{5}$ \\ ${ }^{1}$ Department of Bioresources and Food Science, Konkuk University, \\ 120 Neungdong-ro, Gwangjin-gu, Seoul, Korea
}

\begin{abstract}
Many studies have been carried out with respect to packaging methods and temperature conditions of beef. However, the effects of packaging methods and temperature conditions on the quality characteristics have not been extensively studied in lowgrade beef. Low-grade beef samples were divided into 3 groups (C: ziplock bag packaging, T1: vacuum packaging, and T2: modified atmosphere packaging (MAP), $\mathrm{CO}_{2} / \mathrm{N}_{2}=3: 7$ ) and samples were stored at $4{ }^{\circ} \mathrm{C}$ for 21 days. The water-holding capacity (WHC) was significantly lower in $\mathrm{T} 1$ than in the other samples up to 14 days of storage. The thiobarbituric acid reactive substances and volatile basic nitrogen values were significantly lower in $\mathrm{T} 1$ and $\mathrm{T} 2$ than in $\mathrm{C}$ after 7 to 14 days of storage. The total bacterial counts were significantly lower in $\mathrm{T} 1$ and $\mathrm{T} 2$ than in $\mathrm{C}$ after 14 days of storage. In a sensory evaluation, tenderness and overall acceptability were significantly higher in $\mathrm{T} 1$ and $\mathrm{T} 2$ than in $\mathrm{C}$ at the end of the storage period (21 days). We propose that the MAP method can improve beef quality characteristics of low-grade beef during cold storage. However, the beneficial effects did not outweigh the cost increase to implement MAP. (Key Words: Low-grade Beef, Modified Atmosphere Packaging, Aging, Meat Quality)
\end{abstract}

\section{INTRODUCTION}

The role of food packaging is being increasingly recognized, as it has multiple functions such as product protection, identification, promotion and convenience, and is very important in increasing product shelf life by retarding quality degradation and ensuring safety (Gómez and Lorenzo, 2012). Traditional packaging technologies used for fresh meat and processed meat products have consisted primarily of vacuum packaging, modified atmosphere packaging (MAP), and air-permeable packaging (Lee, 2010). MAP is considered to be an effective method

\footnotetext{
* Corresponding Author: S. K. Jin. Tel: +82-55-751-3283, Fax: +82-55-751-3280, E-mail: skjin@gntech.ac.kr

2 Department of Animal Resources Technology, Gyeongnam National University of Science and Technology, Gyeongnam, Jinju, Chilam-dong 150, Korea.

${ }^{3}$ Swine Science and Technology Center, Gyeongnam National University of Science and Technology, Jinju, Chilam-dong 53210 , Korea.

${ }^{4}$ Department of Physical Education, Chinju National University of Education, Gyeongnam, Jinju, Shinan-dong 380, Korea.

5 Food Safety Division, Seoul Metropolitan Government, 39 Sejongdaero, Jung-gu, Seoul, Korea.

Submitted Apr. 16, 2013; Accepted Aug. 5, 2013; Revised Aug. 18, 2013
}

of food preservation (Chouliara et al., 2007). It is a wellknown method for extending the shelf life of a variety of foods, including fresh meat and poultry (Chouliara et al., 2007). In general, MAP can be classified into 2 main categories: low (including vacuum packaging, $\mathrm{CO}_{2}$ gas flushing, and $\mathrm{N}_{2}$ gas flushing) and high-oxygen modified atmospheres (Seydim et al., 2006). MAP of red meat for retail sale can prolong the microbiological shelf life when compared with traditional oxygen-permeable overwrap (Wicklund et al., 2006). Vacuum packaging followed by refrigerated storage is the most effective method currently used for shelf life extension of uncooked meats (Jayasingh et al., 2001). However, consumer acceptance of vacuumpackaged retail beef has been low because of its dark reddish purple color (Jayasingh et al., 2001). Packaging methods and storage conditions are closely related to the quality of the red meat. However, it is currently not known how MAP and storage conditions improve the quality of low-grade beef during cold storage.

In general, aging of meat can be considered to be the main factor that affects tenderness; therefore, many studies have focused on the ultrastructural changes that occur during aging (Moya et al., 2001). It is well known that extended aging of meat improves the tenderness of pork 
(Therkildsen et al., 2012). However, the rate of aging varies strongly among species and muscles (Clerjon et al., 2011). As tenderness is the main factor involved in $80 \%$ of consumer repurchases, better control of aging is a major economic challenge (Clerjon et al., 2011). Thus, there are methods (aging at $10^{\circ} \mathrm{C}$ to $15^{\circ} \mathrm{C}$ ) available that can improve the tenderness of pork, although they have not been implemented commercially (Therkildsen et al., 2012). Many studies have been carried out with respect to packaging methods and temperature conditions of beef. However, the effects of packaging methods and temperature conditions on the quality characteristics have not been extensively studied in low-grade beef; the storage length of low-grade beef in different storage conditions is largely unknown. Therefore, the aim of this study was to determine the effect of MAP and vacuum packaging methods on the quality characteristics and shelf life of low-grade beef during storage.

\section{MATERIALS AND METHODS}

\section{Animal and sample preparation}

Eighteen cattle (30 months old, with a mean weight of $650 \mathrm{~kg}$ ) were obtained from a local cattle farm. The meat grade system in Korea and beef quality grades, in addition to the color of lean, firmness and texture of lean, and maturity and color of fat, are based on the amount of marbling present in the exposed longissimus dorsi muscle at the 13th rib interface (Korean Carcass Grading Standard, 2010). In this study, carcasses used were quality graded 3 with yield grade B (3B). After the meat grade was judged, the $M$. longissimus dorsi (from the 7 th thoracic vertebrae to the last lumbar vertebrae, LD) were removed from the right side of the carcass $24 \mathrm{~h}$ postmortem in a commercial slaughterhouse. The LD muscles were cut into 5 equal-sized samples (mean weight, $1.5 \mathrm{~kg}$ ), and then a total $90 \mathrm{LD}$ samples were divided into 3 groups [C: ziplock bag $\left(\mathrm{O}_{2}\right.$ permeability, $80 \mathrm{~mL} \mathrm{O}_{2} / \mathrm{m}^{2} / 24 \mathrm{~h}$ at $0^{\circ} \mathrm{C}$ ) packaging, $\mathrm{T} 1$ : vacuum (nylon/polyethylene, $\mathrm{O}_{2}$ permeability, $9.5 \mathrm{~mL}$ $\mathrm{O}_{2} / \mathrm{m}^{2} / 24 \mathrm{~h}$ at $0^{\circ} \mathrm{C}$ ) packaging, and T2: MAP (polyvinylidene chloride, $\mathrm{O}_{2}$ permeability, $0.3 \mathrm{~mL} \mathrm{O}_{2} / \mathrm{m}^{2} / 24$ $\mathrm{h}$ at $\left.\left.0^{\circ} \mathrm{C}\right)\left(\mathrm{CO}_{2} / \mathrm{N}_{2}=3: 7\right)\right]$ and then packaged by using a vacumm chamber (VAC-762F, Jores, Doral, FL. USA). After packaging, the meat samples were stored at $4{ }^{\circ} \mathrm{C}$ for 21 days, and the quality characteristics of the meat samples were analyzed after $1,7,14$, and 21 days of storage.

\section{pH}

$\mathrm{pH}$ was measured using a digital $\mathrm{pH}$ meter (Model 420A, Orion, Waltham, MA, USA). The meat ( $5 \mathrm{~g}$ ) was cut into small pieces, and then $45 \mathrm{~mL}$ of distilled water was added. A slurry was made using a blender, and the $\mathrm{pH}$ was recorded.

\section{Water-holding capacity}

The water-holding capacity (WHC) was determined using a modified version of the method described by Puolanne and Ruusunen (Puolanne and Ruusunen, 1978). The samples $(5 \mathrm{~g})$ were centrifuged at $5^{\circ} \mathrm{C}$ at $1,000 \times g$ for $15 \mathrm{~min}$. The WHC was determined as liquid loss and expressed as percentage of weight of liquid release. WHC $\%=$ (weight before centrifuge-weight after centrifuge $) /($ weight before centrifuge $) \times 100$.

\section{Shear force and texture properties}

The samples (500 g LD) were placed in polyethylene bags and cooked in a $100^{\circ} \mathrm{C}$ water bath until an internal temperature of $75^{\circ} \mathrm{C}$ was reached. Five cylindrical pieces ( $3.5 \mathrm{~cm}$ wide and $3 \mathrm{~cm}$ thick) were tempered at $20^{\circ} \mathrm{C}$ before measuring. The samples were sheared once through the center using an Instron 3343 (US/MX50, A\&D Co., Norwood, MA, USA) equipped with a Warner-Bratzler shearing device $(100 \mathrm{~mm} / \mathrm{min}$ crosshead speed). The shear force value (in kilograms) was the mean of the maximum force required to shear test each core sample. Texture properties were measured using a texture analyzer (EZ-test, Shimadzu, Tokyo, Japan) equipped with a cylindrical plunger (diameter: $5 \mathrm{~mm}$; depression speed: $66 \mathrm{~mm} / \mathrm{min}$ ).

\section{Color}

Color parameters (CIE L* [lightness], a* [redness], b* [yellowness]) were measured using a colorimeter (Minolta, CR-400, Tokyo, Japan) after blooming for 15 min with measurements standardized with respect to the white calibration plate. The chroma $\left(\mathrm{C}^{*}\right)$ and hue angle were calculated as $\left(a^{* 2}+b^{* 2}\right)^{1 / 2}$ and $\operatorname{Tan}^{-1}\left(b^{*} / a^{*}\right)$, respectively (Fernández-López et al., 2000). Five readings were made on each sample in different positions and directions to avoid any orientation effects of the muscle fibers.

\section{Lipid oxidation (thiobarbituric acid reactive substances)}

The thiobarbituric acid reactive substances (TBARS) value as a lipid oxidation value was determined using a modified version of the method described by Buege and Aust (Buege and Aust, 1978). Briefly, $5 \mathrm{~g}$ of sample was weighed into a 50-mL test tube and homogenized with 15 $\mathrm{mL}$ of deionized distilled water for $10 \mathrm{~s}$ at its highest speed. Next, $1 \mathrm{~mL}$ of sample homogenate was transferred to a disposable test tube $(13 \times 100 \mathrm{~mm})$, after which butylated hydroxyanisole $(50 \mu \mathrm{L}, 10 \%)$ and thiobarbituric acid/ trichloroacetic acid (TBA/TCA; $2 \mathrm{~mL}$ ) were added. The mixture was then vortexed and incubated in a boiling water bath for $15 \mathrm{~min}$ to develop the color. The sample was vortexed again and centrifuged for $15 \mathrm{~min}$ at $2,000 \times g$. The absorbance of the resulting supernatant solution was 
determined at $531 \mathrm{~nm}$.

\section{Volatile basic nitrogen}

The volatile basic nitrogen $(\mathrm{VBN})$ was measured as a protein deterioration value using a modified version of the method described by Pearson (Pearson, 1976). Briefly, 10 $\mathrm{mL}$ of sample and a few drops of phenolphthalein indicator (0.5 wt $\%$ solution in $50 \mathrm{wt} \%$ ethanol) were placed in a distillation flask, and then $3.5 \mathrm{~mL}$ of $20 \%$ sodium hydroxide solution was added. The apparatus was then immediately sealed, and the end of the steam distillate was collected in a flask containing $20 \mathrm{~mL}$ of $4 \%$ boric acid and a few drops of Tashiro indicator (methyl red-methylene blue $=2: 1$ ). The steam distillation procedure was continued until $250 \mathrm{~mL}$ of distillate had been collected. Next, the obtained basic solution was titrated against $0.01-\mathrm{M}$ hydrochloric acid to the end point, which was indicated by a green to gray color change. The VBN content was determined after blank correction that was determined by the steam distillation of $6 \%$ perchloric acid.

\section{Microorganisms}

Microorganisms were analyzed for total plate count and number of lactic acid bacteria and Escherichia coli colonies according to standard procedures (Speck, 1992). The TPC and lactic acid bacteria were incubated for $72 \mathrm{~h}$ at $37^{\circ} \mathrm{C}$, and E. coli was incubated for $24 \mathrm{~h}$ at $37^{\circ} \mathrm{C}$. The relevant colonies on the plates were counted, and the results are expressed as colony-forming units (CFU) per gram of meat sample. The TPC counts were then normalized with logarithm on base 10 .

\section{Sensory evaluation}

Sensory evaluation was performed by a panel of 15 trained panelists. Panel development was conducted according to the prescreening, screening, training, and performance evaluation phases proposed by Cross et al. (Cross et al., 1978). The panel evaluated each treatment within each replication in quintuplicate, and the evaluation was performed with the samples at room temperature. Triplicate responses were taken to monitor the inherent texture variability associated with each sample. One slice, $0.5 \mathrm{~cm}$ thick and $5 \mathrm{~cm}$ in diameter, was cut into 6 pieshaped wedges and presented to each panelist. The panelists chose 3 of the most characteristic wedges to avoid a sample containing large pieces of connective tissue. The color, hardness, flavor, off-odor, tenderness, juiciness, and overall acceptability were then evaluated using a 9-point scale.

\section{Statistical analysis}

Statistical analyses were conducted for 3 batches of samples. Data for each batch were analyzed for $\mathrm{pH}$, WHC, shear force, texture properties, color, TBARS, VBN, microorganisms, and sensory evaluation using the SAS software (SAS, 2001) by the generalized linear model procedure. The Student-Newman-Keuls multiple range test was used to compare differences between means.

\section{RESULTS AND DISCUSSION}

The influence of packaging methods and temperature on $\mathrm{pH}, \mathrm{WHC}$, and shear force on low-grade beef is presented in Table 1 . The $\mathrm{pH}$ was significantly higher in $\mathrm{C}$ (ziplock bag packaging) than in $\mathrm{T} 1$ (vacuum packaging) and $\mathrm{T} 2$ (MAP) after 14 days of storage. The WHC was significantly higher in the $\mathrm{C}$ and $\mathrm{T} 2$ samples than in the $\mathrm{T} 1$ samples up to 14 days of storage, and then the WHC did not differ significantly between samples at the end of the storage period. The shear force was significantly decreased with storage period in all the samples; however, the shear force showed no significant difference between the samples during cold storage. In general, WHC and shear force are influenced by packaging methods or $\mathrm{pH}$ decreases. In particular, vacuum packaging can cause increasing drip loss, likely due to the squeezing of the meat during vacuum packaging (Payne et al., 1998). In this study, the WHC was

Table 1. Effects of packaging and aging methods on the $\mathrm{pH}$, WHC, and shear force of low-grade beef during storage

\begin{tabular}{lccccc}
\hline \multirow{2}{*}{ Items } & Treatments $^{1}$ & \multicolumn{4}{c}{ Storage $(\mathrm{d})$} \\
\cline { 3 - 6 } & & 1 & 7 & 14 & 21 \\
\hline $\mathrm{pH}$ & $\mathrm{C}$ & $5.56^{\mathrm{c}, 2} \pm 0.46$ & $5.61^{\mathrm{c}} \pm 0.37$ & $5.77^{\mathrm{Ab}} \pm 0.21$ & $6.38^{\mathrm{Aa}} \pm 0.50$ \\
& $\mathrm{~T} 1$ & $5.56 \pm 0.23$ & $5.62 \pm 0.69$ & $5.53^{\mathrm{B}} \pm 0.35$ & $5.54^{\mathrm{B}} \pm 0.36$ \\
WHC $(\%)$ & $\mathrm{T} 2$ & $5.58 \pm 0.65$ & $5.64 \pm 0.18$ & $5.60^{\mathrm{B}} \pm 0.27$ & $5.47^{\mathrm{B}} \pm 0.38$ \\
& $\mathrm{C}$ & $62.20^{\mathrm{A}} \pm 1.23$ & $62.01^{\mathrm{A}} \pm 2.10$ & $62.29^{\mathrm{AB}} \pm 1.54$ & $66.06 \pm 2.36$ \\
& $\mathrm{~T} 1$ & $54.18^{\mathrm{B}} \pm 0.98$ & $56.04^{\mathrm{B}} \pm 1.45$ & $60.11^{\mathrm{B}} \pm 2.10$ & $62.77 \pm 3.78$ \\
Shear force $(\mathrm{kg})$ & $\mathrm{T} 2$ & $63.31^{\mathrm{A}} \pm 1.85$ & $66.57^{\mathrm{A}} \pm 2.31$ & $67.62^{\mathrm{A}} \pm 1.69$ & $67.12 \pm 4.86$ \\
& $\mathrm{C}$ & $9.09^{\mathrm{a}} \pm 1.00$ & $7.80^{\mathrm{b}} \pm 1.19$ & $4.65^{\mathrm{c}} \pm 0.84$ & $4.76^{\mathrm{c}} \pm 1.33$ \\
& $\mathrm{~T} 1$ & $8.05^{\mathrm{a}} \pm 0.98$ & $8.89^{\mathrm{a}} \pm 1.02$ & $4.71^{\mathrm{b}} \pm 1.93$ & $4.83^{\mathrm{b}} \pm 2.14$ \\
& $\mathrm{~T} 2$ & $8.05^{\mathrm{a}} \pm 1.34$ & $8.27^{\mathrm{a}} \pm 2.10$ & $5.31^{\mathrm{b}} \pm 1.04$ & $5.45^{\mathrm{b}} \pm 1.85$ \\
\hline
\end{tabular}

${ }^{1} \mathrm{C}$ : ziplock bag packaging, T1: vacuum packaging, and T2: $\mathrm{MAP}\left(\mathrm{CO}_{2} / \mathrm{N}_{2}=3: 7\right)$.

$2 \mathrm{~A}-\mathrm{C}$ Means \pm SD with different superscripts in the same column differ significantly at $\mathrm{p}<0.05$.

${ }^{\mathrm{a}-\mathrm{c}}$ Means \pm SD with different superscripts in the same row differ significantly at $\mathrm{p}<0.05$. 
significantly higher in $\mathrm{C}$ and $\mathrm{T} 2$ and lower in $\mathrm{T} 1$, which might have been owing to the head space gas pressure being maintained in the package. However, the change of WHC was not related with shear force values and $\mathrm{pH}$ in low-grade beef. Karabagias et al. (Karabagias et al., 2011) reported that the $\mathrm{pH}$ of air-packaged samples increased from 6.4 to 6.8 on day 4 of storage, which reflects the degree of meat spoilage through protein breakdown resulting in the production of free amino acids leading to the formation of more alkaline $\mathrm{NH}_{3}$ and amines (Karabagias et al., 2011). Consistent with these data, we observed a significant increase in the $\mathrm{pH}$ of the air-packaged sample (C) at 14 and 21 days of storage. Moreover, TBARS as a lipid oxidation value and $\mathrm{VBN}$ as a protein degradation value were significantly higher in $\mathrm{C}$ during cold storage in low-grade beef. These data indicate that $\mathrm{pH}$ changes reflect the storage stability of low-grade beef during cold storage. Karabagias et al. (2011) reported that the $\mathrm{pH}$ can decrease during storage owing to the production of lactic acid through lactic acid bacteria metabolism and dissolution of $\mathrm{CO}_{2}$ into the meat aqueous phase. In this study, the $\mathrm{pH}$ was lower in the MAP samples at the end of the storage period (14 and 21 days), which may be a result of $\mathrm{CO}_{2}$ absorption and lactic acid bacteria metabolism. During post-mortem aging, muscle proteins are also subjected to denaturation, which is related to intracellular $\mathrm{pH}$ decline resulting from postmortem anaerobic glycolysis (Laville et al., 2009). Decreasing the $\mathrm{pH}$ in MAP samples could be a consequence of a formation of a cross-linked myosin heavy chain induced by protein oxidation.
The influence of packaging methods and temperature on the textural properties of low-grade beef is presented in Table 2. The textural properties were not significantly different after 14 days of storage in all the samples during cold storage. Hardness was not significantly different between the samples during cold storage; however, cohesiveness, gumminess, chewiness, and adhesiveness were significantly higher in $\mathrm{T} 1$ than in the other samples at the beginning of the storage period (1 to 7 days). In general, increased cohesiveness, gumminess, chewiness, and adhesiveness indicate that the meat has gotten tough. In this study, decreased cohesiveness, gumminess, chewiness, and adhesiveness in T2 indicates that MAP had less influence on toughness during storage under cold storage conditions. Moreover, the MAP method should be less influenced by the squeezing of meat during packaging, which may be the main reason that cohesiveness, gumminess, chewiness, and adhesiveness were lower during cold storage of low-grade beef. The major eating qualities of meat are developed during muscle aging, and it is well established that storage improves meat tenderness (Laville et al., 2009). In general, increasing the aging time will increase tenderness, and WHC is closely related to meat tenderness during aging. In this study, decreased cohesiveness, gumminess, chewiness, and adhesiveness in the MAP samples may be owing to increased WHC during storage.

The influence of packaging methods and temperature on color parameters of low-grade beef is presented in Table 3. Lightness $\left(\mathrm{L}^{*}\right)$ was significantly lower in $\mathrm{T} 2$ than in the other samples at the beginning of storage. Redness $\left(a^{*}\right)$,

Table 2. Effects of packaging and aging methods on the texture properties of low-grade beef during storage

\begin{tabular}{|c|c|c|c|c|c|}
\hline \multirow{2}{*}{ Items } & \multirow{2}{*}{ Treatments $^{1}$} & \multicolumn{4}{|c|}{ Storage $(\mathrm{d})$} \\
\hline & & 1 & 7 & 14 & 21 \\
\hline \multirow[t]{3}{*}{ Hardness (kg) } & $\mathrm{C}$ & $1.24 \pm 0.12$ & $2.01 \pm 0.65$ & $1.24 \pm 0.35$ & $1.27 \pm 0.22$ \\
\hline & $\mathrm{T} 1$ & $1.72 \pm 0.56$ & $1.05 \pm 0.69$ & $1.34 \pm 0.63$ & $1.10 \pm 0.18$ \\
\hline & $\mathrm{T} 2$ & $1.63 \pm 0.36$ & $1.67 \pm 0.48$ & $1.11 \pm 0.14$ & $1.54 \pm 0.37$ \\
\hline \multirow[t]{3}{*}{ Cohesiveness (\%) } & $\mathrm{C}$ & $0.40^{\mathrm{B} 2} \pm 0.05$ & $0.42 \pm 0.08$ & $0.45 \pm 0.20$ & $0.39 \pm 0.19$ \\
\hline & $\mathrm{T} 1$ & $0.54^{\mathrm{A}} \pm 0.08$ & $0.39 \pm 0.25$ & $0.48 \pm 0.17$ & $0.38 \pm 0.11$ \\
\hline & $\mathrm{T} 2$ & $0.45^{\mathrm{AB}} \pm 002$ & $0.47 \pm 0.14$ & $0.63 \pm 0.32$ & $0.41 \pm 0.08$ \\
\hline \multirow[t]{3}{*}{ Springiness (mm) } & $\mathrm{C}$ & $1.03 \pm 0.12$ & $0.92 \pm 0.23$ & $1.10 \pm 0.18$ & $1.03 \pm 0.22$ \\
\hline & $\mathrm{T} 1$ & $1.06 \pm 0.07$ & $1.08 \pm 0.54$ & $1.00 \pm 0.07$ & $1.21 \pm 0.13$ \\
\hline & $\mathrm{T} 2$ & $1.00 \pm 0.10$ & $1.04 \pm 0.68$ & $1.08 \pm 0.20$ & $1.02 \pm 0.09$ \\
\hline \multirow[t]{3}{*}{ Gumminess (kg) } & $\mathrm{C}$ & $0.55^{\mathrm{C}} \pm 0.02$ & $0.83^{\mathrm{A}} \pm 0.12$ & $0.55 \pm 0.23$ & $0.50 \pm 0.02$ \\
\hline & $\mathrm{T} 1$ & $0.92^{\mathrm{A}} \pm 0.05$ & $0.41^{\mathrm{B}} \pm 0.21$ & $0.65 \pm 0.25$ & $0.41 \pm 0.01$ \\
\hline & $\mathrm{T} 2$ & $0.74^{\mathrm{B}} \pm 0.10$ & $0.76^{\mathrm{A}} \pm 0.05$ & $0.61 \pm 0.40$ & $0.64 \pm 0.12$ \\
\hline \multirow[t]{3}{*}{ Chewiness $(\mathrm{kg}, \mathrm{mm})$} & $\mathrm{C}$ & $0.51^{\mathrm{C}} \pm 0.04$ & $0.85^{\mathrm{A}} \pm 0.12$ & $0.60 \pm 0.12$ & $0.51 \pm 0.08$ \\
\hline & $\mathrm{T} 1$ & $0.97^{\mathrm{A}} \pm 0.01$ & $0.44^{\mathrm{B}} \pm 0.08$ & $0.65 \pm 0.08$ & $0.50 \pm 0.17$ \\
\hline & $\mathrm{T} 2$ & $0.74^{\mathrm{B}} \pm 0.02$ & $0.79^{\mathrm{A}} \pm 0.06$ & $0.67 \pm 0.07$ & $0.65 \pm 0.11$ \\
\hline \multirow[t]{3}{*}{ Adhesiveness (\%) } & $\mathrm{C}$ & $0.09^{\mathrm{B}} \pm 0.02$ & $0.15 \pm 0.02$ & $0.17 \pm 0.02$ & $0.20 \pm 0.02$ \\
\hline & $\mathrm{T} 1$ & $0.13^{\mathrm{A}} \pm 0.01$ & $0.12 \pm 0.05$ & $0.12 \pm 0.04$ & $0.15 \pm 0.01$ \\
\hline & $\mathrm{T} 2$ & $0.09^{\mathrm{B}} \pm 0.03$ & $0.16 \pm 0.07$ & $0.11 \pm 0.05$ & $0.21 \pm 0.11$ \\
\hline
\end{tabular}

${ }^{1} \mathrm{C}$ : ziplock bag packaging, T1: vacuum packaging, and T2: $\mathrm{MAP}\left(\mathrm{CO}_{2} / \mathrm{N}_{2}=3: 7\right)$.

${ }^{2} \mathrm{~A}-\mathrm{B}$ Means \pm SD with different superscripts in the same differ column significantly at $\mathrm{p}<0.05$. 
Table 3. Effects of packaging and aging methods on the meat color of low-grade beef during storage

\begin{tabular}{|c|c|c|c|c|c|}
\hline \multirow{2}{*}{ Items } & \multirow{2}{*}{ Treatments $^{1}$} & \multicolumn{4}{|c|}{ Storage (d) } \\
\hline & & 1 & 7 & 14 & 21 \\
\hline \multirow[t]{3}{*}{$\overline{\mathrm{L}^{*}}$} & $\mathrm{C}$ & $43.88^{\mathrm{A} 2} \pm 1.02$ & $42.83 \pm 1.31$ & $44.36 \pm 2.02$ & $46.00 \pm 1.65$ \\
\hline & $\mathrm{T} 1$ & $44.86^{\mathrm{A}} \pm 1.23$ & $42.21 \pm 0.92$ & $43.26 \pm 1.08$ & $45.72 \pm 2.35$ \\
\hline & $\mathrm{T} 2$ & $38.02^{\mathrm{B}} \pm 0.89$ & $43.38 \pm 1.05$ & $43.67 \pm 1.36$ & $43.47 \pm 3.04$ \\
\hline \multirow[t]{3}{*}{$a^{*}$} & $\mathrm{C}$ & $18.47^{\mathrm{A}} \pm 1.23$ & $17.35 \pm 3.02$ & $15.23 \pm 3.56$ & $19.22 \pm 3.78$ \\
\hline & $\mathrm{T} 1$ & $12.30^{\mathrm{B}} \pm 1.61$ & $14.23 \pm 1.05$ & $18.12 \pm 2.45$ & $17.44 \pm 2.91$ \\
\hline & $\mathrm{T} 2$ & $13.18^{\mathrm{B}} \pm 1.48$ & $19.29 \pm 2.89$ & $16.09 \pm 3.07$ & $17.80 \pm 3.65$ \\
\hline \multirow[t]{3}{*}{$b^{*}$} & $\mathrm{C}$ & $8.01^{\mathrm{A}} \pm 1.23$ & $6.00 \pm 2.14$ & $5.77 \pm 3.01$ & $7.11 \pm 2.14$ \\
\hline & $\mathrm{T} 1$ & $3.69^{\mathrm{B}} \pm 0.58$ & $4.57 \pm 3.16$ & $5.69 \pm 2.12$ & $7.07 \pm 1.25$ \\
\hline & $\mathrm{T} 2$ & $3.35^{\mathrm{B}} \pm 1.31$ & $6.58 \pm 2.87$ & $5.80 \pm 0.87$ & $6.55 \pm 2.87$ \\
\hline \multirow[t]{3}{*}{$\mathrm{C}^{*}$} & $\mathrm{C}$ & $20.13^{\mathrm{A}} \pm 2.13$ & $18.36 \pm 5.23$ & $16.28 \pm 3.65$ & $20.49 \pm 3.15$ \\
\hline & $\mathrm{T} 1$ & $12.84^{\mathrm{B}} \pm 2.01$ & $14.94 \pm 4.69$ & $19.00 \pm 4.56$ & $18.82 \pm 2.56$ \\
\hline & $\mathrm{T} 2$ & $15.60^{\mathrm{B}} \pm 1.56$ & $20.39 \pm 6.54$ & $17.53 \pm 3.78$ & $18.97 \pm 417$ \\
\hline
\end{tabular}

${ }^{1} \mathrm{C}$ : ziplock bag packaging, T1: vacuum packaging, and T2: $\mathrm{MAP}\left(\mathrm{CO}_{2} / \mathrm{N}_{2}=3: 7\right)$.

${ }^{2 \mathrm{~A}-\mathrm{B}}$ Means $\pm \mathrm{SD}$ with different superscripts in the same column differ significantly at $\mathrm{p}<0.05$.

yellowness $\left(\mathrm{b}^{*}\right)$, and chroma $\left(\mathrm{C}^{*}\right)$ were significantly higher in $\mathrm{C}$ than in the other samples at the beginning of storage, whereas there was no difference in these values after 7 days of storage. A high-oxygen atmosphere preserves the bright red color of meat; however, a high concentration of oxygen leads to increased lipid oxidation in meat and meat products, causing increased rancidity (Lund et al., 2007). Low oxygen concentrations favor oxidation of oxymyoglobin to metmyoglobin; therefore, to minimize metmyoglobin formation in fresh red meat, oxygen must be excluded from the packaging environment to below $0.05 \%$ or be present at saturating levels (Kerry et al., 2006). In general, $\mathrm{CO}_{2}$ has positive (reduction of lipid oxidation and control of microorganisms) and negative effects (color deterioration) in meat packaging during storage. Viana et al. (2005) reported that the major disadvantage of high $\mathrm{CO}_{2}$ concentrations in meat MAP is a certain degree of darkening as a result of metmyoglobin formation. On the contrary, Jeremiah et al. (1995) reported that pork packaged with $100 \% \mathrm{CO}_{2}$ had great color stability, and Sørheim et al. (1997) reported that $\mathrm{CO}_{2}$ had no effect on meat color. In this study, the color parameters of all the samples showed no significant difference after 1 day of storage. These results indicate that high $\mathrm{CO}_{2}$ concentrations in meat packaging have less influence on the color of low-grade beef under cold storage conditions. Myoglobin is the principle protein responsible for meat color and accumulation of metmyoglobin at the meat surface is the major factor leading to meat discoloration during aging. Gases in MAP can be influenced myoglobin redox chemistry and thus affect meat color. However, there was no difference in color parameters of all the samples after 1 day of storage in this study. This result indicate that myoglobin redox chemistry may be less influenced by packaging methods of low-grade beef during cold aging. High redness and low yellowness values are better for consumer choice because decreased redness is associated with rancidity and increased yellowness of the fat is assumed to be due to lipid oxidation. Taken together, consumer choice of meat color may be less influenced by packaging methods of low-grade beef during cold storage.

The influence of packaging methods and temperature on TBARS as a lipid oxidation value in low-grade beef is presented in Table 4. The TBARS value increased significantly with storage periods in all the samples. The TBARS value was significantly lower in $\mathrm{T} 1$ and $\mathrm{T} 2$ than in $\mathrm{C}$ after 7 days of storage. Numerous studies have reported that $\mathrm{CO}_{2}$ and vacuum packaging result in less lipid oxidation than aerobic packaging. Lund et al. (2007) also reported that packaging with $100 \%$ nitrogen produced

Table 4. Effect of packaging and aging methods on the TBARS of low-grade beef during storage

\begin{tabular}{|c|c|c|c|c|}
\hline \multirow{2}{*}{ Treatments ${ }^{1}$} & \multicolumn{4}{|c|}{ Storage (d) } \\
\hline & 1 & 7 & 14 & 21 \\
\hline $\mathrm{C}$ & $0.21^{\mathrm{c}} \pm 0.05$ & $0.50^{\mathrm{Ab}} \pm 0.01$ & $0.59^{\mathrm{Ab}} \pm 0.04$ & $0.76^{\mathrm{Aa}} \pm 0.05$ \\
\hline $\mathrm{T} 1$ & $0.13^{\mathrm{c}} \pm 0.02$ & $0.28^{\mathrm{Bb}} \pm 0.02$ & $0.37^{\mathrm{Bb}} \pm 0.02$ & $0.60^{\mathrm{Ba}} \pm 0.03$ \\
\hline $\mathrm{T} 2$ & $0.14^{\mathrm{c}} \pm 0.01$ & $0.24^{\mathrm{Bc}} \pm 0.01$ & $0.49^{\mathrm{ABb}} \pm 0.07$ & $0.62^{\mathrm{Ba}} \pm 0.02$ \\
\hline
\end{tabular}

${ }^{1} \mathrm{C}$ : ziplock bag packaging, T1: vacuum packaging, T2: $\mathrm{MAP}\left(\mathrm{CO}_{2} / \mathrm{N}_{2}=3: 7\right)$, and MA: malondialdehyde.

${ }^{2 \mathrm{~A}-\mathrm{B}}$ Means \pm SD with different superscripts in the same column differ significantly at $\mathrm{p}<0.05$.

${ }^{a-c}$ Mean \pm SD with different superscripts in the same column differ significantly at $\mathrm{p}<0.05$. 
Table 5. Effects of packaging and aging methods on the VBN of low-grade beef during storage

\begin{tabular}{|c|c|c|c|c|}
\hline \multirow{2}{*}{ Treatments $^{1}$} & \multicolumn{4}{|c|}{ Storage (d) } \\
\hline & 1 & 7 & 14 & 21 \\
\hline $\mathrm{C}$ & $9.43^{\mathrm{b} 2} \pm 0.23$ & $10.00^{\mathrm{b}} \pm 0.35$ & $16.76^{\mathrm{Aa}} \pm 0.54$ & $19.70^{\mathrm{Aa}} \pm 0.69$ \\
\hline $\mathrm{T} 1$ & $9.24 \pm 0.45$ & $10.13 \pm 0.99$ & $12.70^{\mathrm{B}} \pm 0.35$ & $12.14^{\mathrm{B}} \pm 0.35$ \\
\hline $\mathrm{T} 2$ & $8.78 \pm 0.65$ & $8.92 \pm 0.67$ & $12.73^{\mathrm{B}} \pm 0.25$ & $12.68^{\mathrm{B}} \pm 0.45$ \\
\hline
\end{tabular}

${ }^{1} \mathrm{C}$ : ziplock bag packaging, T1: vacuum packaging, and T2: $\mathrm{MAP}\left(\mathrm{CO}_{2} / \mathrm{N}_{2}=3: 7\right)$.

$2 \mathrm{~A}-\mathrm{B}$ Means $\pm \mathrm{SD}$ with different superscripts in the same column differ significantly at $\mathrm{p}<0.05$.

${ }^{\mathrm{a}-\mathrm{b}}$ Means \pm SD with different superscripts in the same row differ significantly at $\mathrm{p}<0.05$.

significantly lower TBARS values than packaging in a high-oxygen atmosphere. The results of this study also showed that lipid oxidation was significantly lower in vacuum packaging (T1) and MAP (T2) than in ziplock bag packaging (C) during cold storage. These findings may have been due to the lower oxygen content in the vacuumpackaged and MAP meat than that in the ziplock bagpackaged meat. Reduction of lipid oxidation in MAP samples may be explained by the presence of very low levels of $\mathrm{O}_{2}$ in the packages (Karabagias et al., 2011). Thus, MAP can lead to the reduction of lipid oxidation during cold storage. In general, the stability of meat pigments such as oxymyoglobin is highly influenced by lipid oxidation. In this study, lipid oxidation was decreased by the MAP method (Table 4), whereas decreasing lipid oxidation had less influence on meat color parameters in low-grade beef during cold storage because color parameters were not significantly different among samples after 7 days of storage. Bingol and Ergun (2011) reported that meat packages with high $\mathrm{CO}_{2}$ concentrations had lower mean TBARS values than meat in $\mathrm{O}_{2}$ packages for ostrich meat. Jakobsen and Bertelsen (2002) also reported that $\mathrm{CO}_{2}$ decreased the lipid oxidation rate in meat, which was attributed to $\mathrm{pH}$ reduction due to the absorption of $\mathrm{CO}_{2}$. However, some studies found intense discoloration in meat surfaces when using anoxic MAP conditions (Karabagias et al., 2011). Therefore, discoloration may depend on the composition of the atmosphere in the MAP system. MAP is an extremely important packaging technique used extensively for the distribution, storage, and display of meat products in markets with a controlled cold distribution chain (Sivertsvik et al., 2002). Lipid oxidation is generally associated with low residual oxygen levels. Thus, vacuum packaging (T1) and the MAP method can improve the shelf life and consumer acceptance of low-grade beef with less color deterioration during cold storage.

The influence of packaging methods and temperature on $\mathrm{VBN}$ as a protein deterioration value in low-grade beef is presented in Table 5. The VBN value was significantly lower in $\mathrm{T} 1$ and $\mathrm{T} 2$ than in $\mathrm{C}$ after 14 days of storage. However, the VBN value did not differ significantly between $\mathrm{T} 1$ and $\mathrm{T} 2$ during cold storage. In meat, protein oxidation may decrease the eating quality by reducing tenderness and juiciness and increasing flavor deterioration and discoloration (Lund et al., 2007). Lund et al. (2007) also reported that oxidation plays a role in controlling the proteolytic activity of enzymes and therefore influences meat tenderness. Thus, vacuum packaging (T1) and the MAP (T2) methods can prevent protein deterioration in low-grade beef during cold storage.

The influence of packaging methods and temperature on microorganisms in low-grade beef is presented in Table 6.

Table 6. Effects of packaging and aging methods on the microorganisms in low-grade beef during storage

\begin{tabular}{lccccc}
\hline \multirow{2}{*}{ Items } & Treatments $^{1}$ & \multicolumn{4}{c}{ Storage (d) } \\
\cline { 3 - 6 } Total bacterial counts & & 1 & 7 & 14 & 21 \\
& $\mathrm{C}$ & $3.12^{\mathrm{Ac}} \pm 0.12$ & $3.46^{\mathrm{Ac}} \pm 0.23$ & $4.45^{\mathrm{Ab}} \pm 0.24$ & $6.89^{\mathrm{Aa}} \pm 0.12$ \\
& $\mathrm{~T} 1$ & $3.01^{\mathrm{Ac}} \pm 0.09$ & $3.02^{\mathrm{Ac}} \pm 0.14$ & $4.03^{\mathrm{ABb}} \pm 0.22$ & $6.40^{\mathrm{Ba}} \pm 0.14$ \\
Lactic acid bacteria & $\mathrm{T} 2$ & $2.05^{\mathrm{Bc}} \pm 0.07$ & $2.15^{\mathrm{Bc}} \pm 0.09$ & $3.00^{\mathrm{Bb}} \pm 0.10$ & $6.06^{\mathrm{Ca}} \pm 0.21$ \\
& $\mathrm{C}$ & $2.02^{\mathrm{C}} \pm 0.05$ & $2.65^{\mathrm{Ac}} \pm 0.11$ & $3.95^{\mathrm{Ab}} \pm 0.25$ & $5.65^{\mathrm{Ba}} \pm 0.25$ \\
& $\mathrm{~T} 1$ & $1.95^{\mathrm{c}} \pm 0.15$ & $2.05^{\mathrm{Bc}} \pm 0.08$ & $2.60^{\mathrm{Bb}} \pm 0.31$ & $5.46^{\mathrm{Ba}} \pm 0.33$ \\
E. coli & $\mathrm{T} 2$ & $2.55^{\mathrm{c}} \pm 0.45$ & $3.12^{\mathrm{Ac}} \pm 0.07$ & $4.32^{\mathrm{Ab}} \pm 0.17$ & $6.15^{\mathrm{Aa}} \pm 0.21$ \\
& $\mathrm{C}$ & $0.99^{\mathrm{b}} \pm 0.08$ & $1.55^{\mathrm{Ab}} \pm 0.08$ & $1.95^{\mathrm{Ab}} \pm 0.04$ & $2.85^{\mathrm{a}} \pm 0.23$ \\
& $\mathrm{~T} 1$ & $0.84^{\mathrm{b}} \pm 0.06$ & $1.02^{\mathrm{Bb}} \pm 0.10$ & $1.15^{\mathrm{Bb}} \pm 0.15$ & $2.66^{\mathrm{a}} \pm 0.08$ \\
& $\mathrm{~T} 2$ & $1.05^{\mathrm{c}} \pm 0.12$ & $1.74^{\mathrm{Ab}} \pm 0.12$ & $2.24^{\mathrm{Ab}} \pm 0.07$ & $3.25^{\mathrm{a}} \pm 0.11$ \\
\hline
\end{tabular}

${ }^{1} \mathrm{C}$ : ziplock bag packaging, T1: vacuum packaging, and T2: $\mathrm{MAP}\left(\mathrm{CO}_{2} / \mathrm{N}_{2}=3: 7\right)$.

2 A-C Means \pm SD with different superscripts in the same column differ significantly at $p<0.05$.

${ }^{\mathrm{a}-\mathrm{c}}$ Means $\pm \mathrm{SD}$ with different superscripts in the same row differ significantly at $\mathrm{p}<0.05$. 
The number of microorganisms increased with cold storage in all the samples. The total bacterial counts were significantly lower in $\mathrm{T} 1$ and $\mathrm{T} 2$ than in $\mathrm{C}$ after 14 days of storage. However, lactic acid bacteria was significantly lower in T1 after 7 days of storage, and E. coli levels were significantly lower in $\mathrm{T} 1$ than in the other samples at 7 and 14 days of storage. An increase in the $10^{6}$ to $10^{8} \mathrm{CFU} / \mathrm{g}$ range has been shown to be associated with meat spoilage associated with an off-odor and possible slime development (Seydim et al., 2006). In this study, the $10^{6}$ to $10^{8} \mathrm{CFU} / \mathrm{g}$ range was reached after 21 days of storage in all the samples. Based on the results of microorganisms, we assume that an appropriate shelf life of low-grade beef may be 14 days. Anoxic environments retard microbial growth and delay spoilage owing to the slow proliferation of bacteria capable of tolerating anaerobic conditions (Martínez et al., 2006). Jakobsen and Bertelsen (2002) also reported that elevated levels of $\mathrm{CO}_{2}$ inhibit microbial growth. High $\mathrm{CO}_{2}$ levels (10 to 80\%) are desirable for foods such as meat and poultry to inhibit surface microbial growth and extend shelf life (Kerry et al., 2006). The results of this study showed that total bacterial growth was delayed by MAP (T2), whereas lactic acid bacteria and E. coli growth were significantly lower in $\mathrm{T} 1$. These findings indicate that $\mathrm{CO}_{2}$ and nitrogen were the most effective antimicrobial factors. Based on the results of this study, we assume that the total bacterial count can be decreased by MAP during cold storage without color deterioration. Under aerobic conditions, predominant spoilage organisms are typically Pseudomonas (Gill et al., 2000). In $\mathrm{O}_{2}$-depleted atmospheres of $\mathrm{N}_{2}$ or $\mathrm{CO}_{2}$, the anaerobic conditions prevent all growth of Pseudomonas (Gill et al., 2000). Lactic acid bacteria behave as facultative anaerobes and can grow under high concentrations of $\mathrm{CO}_{2}$, thus lactic acid bacteria constitute a substantial part of the natural microflora of MAP meats (Karabagias et al., 2011). In this study, lactic acid bacteria were increased using the MAP method, which may be owing to the high $\mathrm{CO}_{2}$ levels used $\left(\mathrm{CO}_{2} / \mathrm{N}_{2}=3: 7\right)$. In this study, high $\mathrm{CO}_{2}$ levels in MAP facilitated lactic acid bacteria growth. Thus, we assume that low amounts of $\mathrm{O}_{2}$ could help to control lactic acid bacteria growth in lowgrade beef during cold storage.

The influence of packaging methods and temperature on sensory evaluation in low-grade beef is presented in Table 7. Color, hardness, flavor, and juiciness were not significantly different in all the samples during cold storage. However,

Table 7. Effects of packaging and aging methods on the sensory evaluation of low-grade beef during storage

\begin{tabular}{|c|c|c|c|c|c|}
\hline \multirow{2}{*}{ Items } & \multirow{2}{*}{ Treatments $^{1}$} & \multicolumn{4}{|c|}{ Storage (d) } \\
\hline & & 1 & 7 & 14 & 21 \\
\hline \multirow[t]{3}{*}{ Color $^{3}$} & $\mathrm{C}$ & $5.78 \pm 1.23$ & $5.83 \pm 0.15$ & $6.42 \pm 1.87$ & $6.69 \pm 2.10$ \\
\hline & $\mathrm{T} 1$ & $5.61 \pm 2.30$ & $5.92 \pm 1.29$ & $6.83 \pm 2.23$ & $6.38 \pm 1.56$ \\
\hline & $\mathrm{T} 2$ & $5.61 \pm 0.89$ & $5.92 \pm 0.98$ & $6.75 \pm 1.12$ & $6.44 \pm 1.68$ \\
\hline \multirow[t]{3}{*}{ Hardness } & $\mathrm{C}$ & $5.89 \pm 1.56$ & $5.67 \pm 0.87$ & $5.75 \pm 0.23$ & $5.81 \pm 1.35$ \\
\hline & $\mathrm{T} 1$ & $5.72 \pm 2.69$ & $6.00 \pm 2.35$ & $6.08 \pm 1.25$ & $6.31 \pm 2.00$ \\
\hline & $\mathrm{T} 2$ & $6.11 \pm 3.12$ & $5.92 \pm 3.21$ & $6.42 \pm 1.67$ & $5.69 \pm 1.74$ \\
\hline \multirow[t]{3}{*}{ Flavor } & $\mathrm{C}$ & $6.00 \pm 1.54$ & $6.33 \pm 0.87$ & $6.08 \pm 1.20$ & $4.94 \pm 2.23$ \\
\hline & $\mathrm{T} 1$ & $5.89 \pm 1.36$ & $6.08 \pm 0.96$ & $6.67 \pm 1.30$ & $6.19 \pm 1.87$ \\
\hline & $\mathrm{T} 2$ & $6.11 \pm 1.90$ & $5.92 \pm 0.11$ & $6.67 \pm 1.24$ & $5.50 \pm 1.26$ \\
\hline \multirow[t]{3}{*}{ Off-odor } & $\mathrm{C}$ & $0.33 \pm 0.03$ & $1.00 \pm 0.08$ & $1.52 \pm 0.56$ & $3.50^{\mathrm{A} 2} \pm 0.56$ \\
\hline & $\mathrm{T} 1$ & $0.56 \pm 0.23$ & $1.17 \pm 0.29$ & $1.25 \pm 0.38$ & $1.00^{\mathrm{B}} \pm 0.18$ \\
\hline & $\mathrm{T} 2$ & $0.33 \pm 0.21$ & $1.00 \pm 0.65$ & $1.37 \pm 0.42$ & $1.63^{\mathrm{B}} \pm 0.34$ \\
\hline \multirow[t]{3}{*}{ Tenderness } & $\mathrm{C}$ & $4.39 \pm 1.22$ & $5.42 \pm 1.25$ & $5.42 \pm 1.20$ & $4.50^{\mathrm{B}} \pm 1.41$ \\
\hline & $\mathrm{T} 1$ & $3.89 \pm 1.87$ & $5.50 \pm 1.10$ & $5.83 \pm 1.90$ & $6.06^{\mathrm{A}} \pm 1.02$ \\
\hline & $\mathrm{T} 2$ & $4.50 \pm 1.39$ & $5.92 \pm 1.87$ & $5.83 \pm 1.08$ & $5.81^{\mathrm{A}} \pm 1.23$ \\
\hline \multirow[t]{3}{*}{ Juiciness } & $\mathrm{C}$ & $5.56 \pm 1.25$ & $5.42 \pm 2.01$ & $5.75 \pm 1.48$ & $5.31 \pm 1.22$ \\
\hline & $\mathrm{T} 1$ & $5.39 \pm 1.48$ & $5.58 \pm 1.25$ & $5.83 \pm 1.69$ & $6.13 \pm 1.31$ \\
\hline & $\mathrm{T} 2$ & $5.67 \pm 1.10$ & $5.92 \pm 1.36$ & $5.92 \pm 1.21$ & $5.88 \pm 1.56$ \\
\hline \multirow[t]{3}{*}{ Overall acceptability } & $\mathrm{C}$ & $5.88 \pm 0.85$ & $5.80 \pm 0.13$ & $5.90 \pm 0.89$ & $5.29^{\mathrm{B}} \pm 0.09$ \\
\hline & $\mathrm{T} 1$ & $5.56 \pm 0.39$ & $6.20 \pm 1.04$ & $6.48 \pm 1.08$ & $5.93^{\mathrm{AB}} \pm 1.02$ \\
\hline & $\mathrm{T} 2$ & $5.88 \pm 1.23$ & $6.30 \pm 1.36$ & $6.50 \pm 1.00$ & $6.29^{\mathrm{A}} \pm 0.87$ \\
\hline
\end{tabular}

${ }^{1} \mathrm{C}$ : ziplock bag packaging, T1: vacuum packaging, and T2: $\mathrm{MAP}\left(\mathrm{CO}_{2} / \mathrm{N}_{2}=3: 7\right)$.

${ }^{2 \mathrm{~A}-\mathrm{B}}$ Means \pm SD with different superscripts in the same column differ significantly at $\mathrm{p}<0.05$.

${ }^{3}$ Color $(9=$ very good and $1=$ very bad $)$, hardness $(9=$ very hard and $1=$ very soft $)$, flavor $(9=$ very good and $1=$ very bad $)$, off-odor $(9=$ very intense and $1=$ very weak $)$, tenderness $(9=$ very tender and $1=$ very tough $)$, juiciness $(9=$ very juicy and $1=$ very dry $)$, and overall acceptability $(9=$ very good and $1=$ very bad). 
off-odor was significantly lower in $\mathrm{T} 1$ and $\mathrm{T} 2$, whereas tenderness and overall acceptability were significantly higher in $\mathrm{T} 1$ and $\mathrm{T} 2$ than in $\mathrm{C}$ at the end of storage (21 days). Sensory characteristics can be affected by packaging methods. Luño et al. (2000) reported that the presence of $50 \% \mathrm{CO}_{2}$ in packing atmospheres helped delay odor changes owing to considerable inhibition of microbial growth. Based on data from this study, we assume that packaging method has a limited effect on the sensory characteristics that occur during cold storage. Rubio et al. (2007) also reported that sensory characteristics were only slightly affected by the MAP packaging system (20/80\% $\mathrm{CO}_{2} / \mathrm{N}_{2}$ ). In general, shelf life and quality of fresh meat are influenced by initial quality, packaging parameters, and storage conditions (Gómez and Lorenzo, 2012). However, the association of sensory evaluation with other meat characteristics such as physicochemical properties, TBA, $\mathrm{VBN}$, or microorganisms was not remarkable in low-grade beef during cold storage.

The results of the present study revealed that the WHC was significantly higher in the $\mathrm{C}$ and $\mathrm{T} 2$ samples than in the T1 samples. The MAP method reduced lipid oxidation and protein deterioration of low-grade beef during cold storage. At the end of the storage period, tenderness and overall acceptability was higher in $\mathrm{T} 1$ and $\mathrm{T} 2$ than in C. Taken together, these data indicate that the MAP method can extend shelf life similarly to vacuum packaging, and the MAP method can improve beef quality characteristics in low-grade beef during cold storage. However, the cost versus beneficial effects of MAP was insufficient because MAP is more expensive than vacuum and ziplock packaging owing to the use of gases and air-impermeable casing. Therefore, more studies are needed to determine how the quality of meat is affected by storage methods and how to improve low-grade meat quality by packaging methods and storage temperature.

\section{ACKNOWLEDGEMENTS}

This work was supported by Priority Research Centers Program through the National Research Foundation of Korea (FRF), funded by the Ministry of Education, Science and Technology. This paper was supported by the SMART Research Professor Program of Konkuk University.

\section{REFERENCES}

Bingol, E. B. and O. Ergun. 2011. Effects of modified atmosphere packaging (MAP) on the microbiological quality and shelf life of ostrich meat. Meat Sci. 88:774-785

Buege, A. J. and S. D. Aust. 1978. Microsomal lipid peroxidation. Method Enzymol. 52:302-310.

Chouliara, E., A. Karatapanis, I. N. Savvaidis, and M. G. Kontominas. 2007. Combined effect of oregano essential oil and modified atmosphere packaging on shelf-life extension of fresh chicken breast meat, stored at $40^{\circ} \mathrm{C}$. Food Microbiol. 24:607-617.

Clerjon, S., F. Peyrin, and J. Lepetit. 2011. Frontal UV-visible fluorescence polarization measurement for bovine meat ageing assessment. Meat Sci. 88:28-35.

Cross, H. R., R. Moen, and M. S. Stanfield. 1978. Training and testing of judges for sensory analysis of meat quality. Food Technol. 32:48-54.

Federation, N. L. C. 2010. National Livestock Cooperatives Federation (NLCF), Korean carcass grading standard. National Livestock Cooperatives Federation.

Fernández-López, J., P. A. José Angel, and V. Aranda-Catalá. 2000. Effect of mincing degree on colour properties in pork meat. Color Res. Appl. 25:376-380.

Gómez, M. and J. M. Lorenzo. 2012. Effect of packaging conditions on shelf-life of fresh foal meat. Meat Sci. 91:513520.

Gill, C. O., T. Jones, J. Bryant, and D. A. Brereton. 2000. The microbiological conditions of the carcasses of six species after dressing at a small abattoir. Food Microbiol. 17:233-239.

Jakobsen, M. and G. Bertelsen. 2002. The use of $\mathrm{CO}_{2}$ in packaging of fresh red meat and its effect on chemical quality changes in the meat: a review. J. Muscle Foods 13:143-168.

Jayasingh, P., D. P. Cornforth, C. E. Carpenter, and D. Whittier. 2001. Evaluation of carbon monoxide treatment in modified atmosphere packaging or vacuum packaging to increase color stability of fresh beef. Meat Sci. 59:317-324.

Jeremiah, L. E., L. L. Gibson, and G. C. Argnosa. 1995. The influence of controlled atmosphere and vacuum packaging upon chilled pork keeping quality. Meat Sci. 40:79-92.

Karabagias, I., A. Badeka, and M. G. Kontominas. 2011. Shelf life extension of lamb meat using thyme or oregano essential oils and modified atmosphere packaging. Meat Sci. 88:109-116.

Kerry, J. P., M. N. O'Grady, and S. A. Hogan. 2006. Past, current and potential utilisation of active and intelligent packaging systems for meat and muscle-based products: A review. Meat Sci. 74:113-130.

Laville, E., T. Sayd, M. Morzel, S. Blinet, C. Chambon, J. Lepetit,G. Ren, and J. F. Hocquette. 2009. Proteome changes during meat aging in tough and tender beef suggest the importance of apoptosis and protein solubility for beef aging and tenderization. J. Agric. Food Chem. 57:10755-10764.

Lee, K. T. 2010. Quality and safety aspects of meat products as affected by various physical manipulations of packaging materials. Meat Sci. 86:138-150.

Luño, M., P. Roncalés, D. Djenane, and J. A. Beltrán. 2000. Beef shelf life in low $\mathrm{O}_{2}$ and high $\mathrm{CO}_{2}$ atmospheres containing different low CO concentrations. Meat Sci. 55:413-419.

Lund, M. N., M. S. Hviid, and L. H. Skibsted. 2007. The combined effect of antioxidants and modified atmosphere packaging on protein and lipid oxidation in beef patties during chill storage. Meat Sci. 76:226-233.

Martínez, L., D. Djenane, I. Cilla, J. A. Beltrán, and P. Roncalés. 2006. Effect of varying oxygen concentrations on the shelf-life of fresh pork sausages packaged in modified atmosphere. Food Chem. 94:219-225.

Moya, V. J., M. Flores, M. C. Aristoy, and F. Toldrá. 2001. Pork meat quality affects peptide and amino acid profiles during the 
ageing process. Meat Sci. 58:197-206.

Payne, S. R., C. J. Durham, S. M. Scott, and C. E. Devine. 1998 The effects of non-vacuum packaging systems on drip loss from chilled beef. Meat Sci. 49:277-287.

Pearson, D. 1976. The chemical analysis of foods. 7th edition Churchill, Livingston, 386.

Puolanne, E. and M. Ruusunen. 1978. Verfahren zur Untersuchung der Eigenschaften von Brühwurstbrät. Fleischwirtschaft 58: 1543-1544.

Rubio, B., B. Martínez, C. González-Fernández, M. D. GarcíaCachán, J. Rovira, and I. Jaime. 2007. Effect of modified atmosphere packaging on the microbiological and sensory quality on a dry cured beef product: "Cecina de león". Meat Sci. 75:515-522.

Sørheim, O., T. Aune, and T. Nesbakken. 1997. Technological, hygienic and toxicological aspects of carbon monoxide used in modified-atmosphere packaging of meat. Trends Food Sci. Technol. 8:307-312.

SAS. 2001. The SAS program for window. The SAS Institute, Inc.
Seydim, A. C., J. C. Acton, M. A. Hall, and P. L. Dawson. 2006. Effects of packaging atmospheres on shelf-life quality of ground ostrich meat. Meat Sci. 73:503-510.

Sivertsvik, M., J. T. Rosnes, and H. T. Bergslien. 2002. Minimal processing technologies in the food industry (Ed. T. Ohlsson and N. Bengtsson). Woodhead Publishing Ltd., Cambridge, UK, 61-86

Speck, M. L. 1992. Compendium of methods for microbiological examination of foods American Public Health Association, 914.

Therkildsen, M., L. Kristensen, S. Kyed, and N. Oksbjerg. 2012. Improving meat quality of organic pork through post mortem handling of carcasses: An innovative approach. Meat Sci. 91:108-115.

Viana, E. S., L. A. M. Gomide, and M. C. D. Vanetti. 2005. Effect of modified atmospheres on microbiological, color and sensory properties of refrigerated pork. Meat Sci. 71:696-705.

Wicklund, R. A., D. D. Paulson, E. M. Tucker, A. J. Stetzer, F. DeSantos, M. Rojas, B. J. MacFarlane, and M. S. Brewer. 2006. Effect of carbon monoxide and high oxygen modified atmosphere packaging and phosphate enhanced, case-ready pork chops. Meat Sci. 74:704-709. 